\title{
Acute effects of caffeine intake on athletic performance: A systematic review and meta-analysis
}

\section{Efectos agudos de la ingesta de cafeína en el rendimiento atlético: Una revisión sistemática y meta-análisis}

\begin{abstract}
Objective: Our objective was to perform a systematic review and meta-analysis of the research literature assessing the effect of caffeine on athletic performance. Methods: A total of 13 studies published between 2010 and 2015 were included in the meta-analysis of the effects of caffeine on maximum running distance (2 studies), time trial performance (7 studies), and muscle power (4 studies). The effect sizes were calculated as standardized differences in means (std in means). Meta-analysis was completed using a random effects model. Results: Caffeine supplementation did not increase maximum running distance (effect size $=$ $0.37, p=0.14$ ) and muscle power (effect size $=0.17, p=$ $0.36)$. However, improvements were observed in the time trial performance (effect size $=-0.40, p<0.01$ ). Subgroup analyses revealed that the improvement in time trial results may be related to the use of the $6 \mathrm{mg} / \mathrm{kg}$ of body weight of caffeine dose (effect size $=-0.45, p=0.01$ ). Conclusion: Our meta-analysis showed that caffeine intake does not improve performance in maximum running distance and muscle power, but it seems to improve time trial performance. The effect of caffeine on time trial performance related to dose. Key Words: caffeine, running, exercise test, cycling, muscle power.
\end{abstract}

\section{INTRODUCTION}

Athletes are always looking for legal ergogenic aids to increase their performance. Ergogenic aids are substances, techniques, or sports equipment that improve sports performance'. Among legal nutritional ergogenic resources, we highlight caffeine (1,3,7-trimethylxanthine), which is one of the most used ergogenic aids by athletes ${ }^{1-3}$. Del Coso et al. ${ }^{1}$ evaluated 20,686 urine samples from athletes of different sports (i.e., handball, triathlon, cycling, rowing, athletics (track and fiels), volleyball, soccer, and swimming) between 2004 and 2008 . They found that $26.2 \%$ of the athletes presented blood caffeine levels below $0.1 \mu \mathrm{g} . \mathrm{ml}-1$ (limit of detection),
Beatriz Gonçalves Ribeiro ${ }^{1,4}$, Anderson Pontes Morales ${ }^{1,2,3,4}$, Felipe Sampaio-Jorge ${ }^{1,2,3}$, Felipe de Souza Tinoco ${ }^{1}$, Alessandra Alegre de Matos ${ }^{1,3}$, Tiago Costa Leite ${ }^{1}$.

1. Laboratory of Research and Innovation in Sports Sciences, Federal University of Rio de Janeiro UFRI, Macaé, Brazil 2. Higher Institutes of Education of CENSA, ISECENSA, Campos dos Goytacazes, Brazil 3. Secretary Municipal of Sport, City, Macaé, Brazil 4. Postgraduate Program in Nutrition, Institute of Nutrition, Federal University of Rio de Janeiro UFRJ, Rio de Janeiro, Brazil.

Corresponding author. Beatriz Gonçalves Ribeiro. Laboratory of Research and Innovation in Sports Sciences, Federal University of Rio de Janeiro - Macaé Campus, RJ, Brazil. 159, Alcides da Conceição, Granja dos Cavaleiros, Macaé, Rio de Janeiro, Brazil 27930-560. Telephone: +552227933-378. E-mail: ribeirogoncalvesb@gmail.com

Este trabajo fue recibido el 3 de marzo de 2017 Aceptado con modificaciones: 28 junio de 2017 Aceptado para publicación: 10 julio de 2017

$67.3 \%$ had below $5 \mu \mathrm{g} . \mathrm{ml}-1$, and only $0.6 \%$ exceeded the threshold of $12 \mu \mathrm{g} . \mathrm{ml}-1$ (i.e., value considered as doping between 1985 and 2004). Following its 2004 removal from the World Anti-Doping Agency (WADA) Prohibited List, caffeine can be considered safe, effective, and legal when used according to established and practiced protocols.

The prevalence of caffeine intake by athletes before and during competition is high, with the substance obtained from various sources, such as energy drinks, energy gels, and tablets, carbonated sodas, and coffee ${ }^{2}$. In previous studies, caffeine doses commonly range from 3 (low) ${ }^{4}, 6$

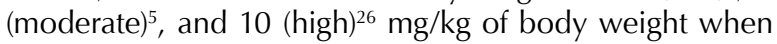


the substance is ingested 30-60 minutes before exercise to allow the caffeine levels in the bloodstream to reach peak values ${ }^{4,5}$.

Caffeine may affect performance through both peripheral and central mechanisms. The mechanism for improved endurance, sprint, and power performance has been related to a simple biologic mechanism, such as glycogen sparing, increased intracellular $\mathrm{Ca}^{++}$concentration, or altered excitation-contraction coupling ${ }^{6-9}$. However, a caffeine paradigm for improved athletic performance is a complex, including biologic mechanisms, and cognitive perception ${ }^{5}$. Davis et al. ${ }^{10}$ proposed a mechanism by which caffeine delays fatigue through its effects on the central nervous system (CNS). Recently, this mechanism has gained popularity because of previously known effects of caffeine as a CNS stimulant, through its action as an adenosine receptor antagonist, and its analgesic effects on the CNS.

Although the physiological basis of caffeine intake is well described, its clinical effect of improving athletic performance remains controversial. Caffeine intake has been reported to be safe to the cardiovascular system that does not cause changes in heart rate, blood pressure and heart rate variability ${ }^{11}$. However, the results are mixed in the context of "strength"12 and "resistance" tests" ${ }^{13,14}$, using different tests to evaluate the strength (i.e., 1-RM test and maximal voluntary contraction - MVC) and endurance (i.e., repetitions until fatigue). This division does not describe the complexity of different tests, and it is difficult to classify tests into only two groups.

A pertinent question is whether the effects of caffeine supplementation are similar in all tests considered "endurance" or "strength" and if these effects could be limited to a subset of these two larger groups. From this perspective, this systematic review and meta-analysis of randomized clinical trials aims to verify whether acute caffeine supplementation improves athletic performance regardless of whether the tests involve "endurance" or "strength", but considering the same types of tests conducted by performance athletic.

\section{MATERIALS AND METHODS}

\section{Systematic Review}

A systematic review of the literature was carried out to analyze the acute effects of caffeine intake on athletic performance, which was defined as: 1 ) the maximum total running distance during the test, 2 ) the time trial performance in exercise, and 3) the muscle power generated during exercise. The search included articles published between January 2010 and December 2015 and was carried out using the PubMed and Bireme databases. The terms used in the search were "caffeine" or "exercise" or "performance" or "drink" or "capsule." Only studies with humans were included.

\section{Inclusion criteria}

The criteria for inclusion in the analysis were: 1) studies with physically active humans (i.e., individuals involved in physical activities of medium slow/medium-intensity physical activities); 2) studies with at least two trials (or separate groups of subjects), in which the subjects consumed caffeine in one trial (or group) and placebo in the other, and 3) studies that showed results in absolute values of the studied variables (i.e., maximum running distance, time trial performance and muscle power).

The exclusion criteria were: 1 ) use of co-ingested caffeine with other known or potential ergogenic compounds (i.e., creatinine, ginseng, and taurine), used sweetened beverages containing caffeine or no sugar; 2 ) trials that included women, children, adolescents, and sedentary men; 3 ) studies that did not have full texts (in such cases, an attempt was made to retrieve the necessary data by e-mailing the author; and 4) duplicity in the two search criteria.

\section{Selection of studies}

Two reviewers (BGR and FSJ) separately carried out a full-text analysis of all eligible articles to independently check if all the inclusion and exclusion criteria were in agreement. Any disagreement between reviewers was discussed. If no agreement was reached, a third reviewer (APM) was consulted.

\section{Data collection}

Two reviewers (BGR and FSJ) independently extracted data from all eligible studies. Any disagreement was resolved as mentioned above. Continuous outcomes, means, and standard deviations were used. For data analysis, the studies were classified under maximum running distance, time trial performance and muscle power. For meta-analysis, the data were generally extracted using means, standard deviations, and sample sizes (n) for both caffeine and placebo conditions. For both treatments in all studies, the mean differences and 95\% confidence intervals $(\mathrm{Cl})$ were calculated for comparison of continuous outcomes by using a random effects model.

Assessment of bias risk and study quality

The systematic error of the 13 studies was assessed using the Cochrane risk of bias tool. The following dimensions were considered: random sequence generation, allocation concealment, blinding of participants, blinding of personnel, blinding of outcome, incomplete outcome data, selective outcome reporting, and other sources of bias. The risk judgement was assessed by using prespecified criteria about the adequacy of the study and was expressed as "low risk of bias," "high risk of bias," or "unclear risk of bias"15.

\section{Meta-analysis}

The meta-analysis was completed using the Comprehensive Meta-analysis software (version 2.2; Biostat Inc., Englewood, NJ). The data were extracted and converted into a standard format by calculating the standardized mean difference (SMD), referred to as "effect size" in the Results and Discussion. 


\section{RESULTS}

DESCRIPTION OF THE INCLUDED STUDIES

Figure 1 illustrates the selection of studies included in the analysis. A total of 13 studies published between 2010 and 2015 were included in the meta-analysis of the effects of caffeine on maximum running distance $(n=2)$, time trial performance $(n=7)$ and muscle power $(n=4)$. The total sample consisted of 174 individuals. The mean age of individuals of the studies varied between 20.8 and 36.2 years. One study, however, did not report the age of the subjects. The dosage of caffeine varied between $\sim 2.5$ and $10 \mathrm{mg} / \mathrm{kg}$ of body weight; one study used a fixed dosage for the whole sample. In this case, to categorize the amount of caffeine consumed, the quantity of consumed caffeine was divided by the mean body mass of the sample. All articles used caffeine in capsules. General characteristic of the studies included on systematic review and meta-analysis are shown in Table 1.

Analysis of the subgroup of quantitative data (Dosage)

Table 2 illustrates the effect sizes of trials related to dosage (maximum running distance, time trial performance and muscle power). The dosage of $6 \mathrm{mg} / \mathrm{kg}$ on the time trial performance was significant with the effect size of -0.45 (-0.81 to $-0.08 ; p=0.01)$. No significant results were identified for the effects for $<6 \mathrm{mg} / \mathrm{kg}$ dosage in the time trial performance $(p=0.18)$. Comparisons with maximum running distance and muscle power were not possible, since few articles were included for analysis in subgroup.

Assessment of quality and publication bias

Two of the studies assessed had a clear description of the random sequence generation (low risk of bias). Only one study reported allocation concealment (low risk of bias). A complete description of blinding of participants (low risk of bias) was observed in 11 studies, and blinding of personnel (low risk of bias) in 8 studies. One article had complete information on blinding of outcome assessors (low risk of bias); one article had incomplete outcomes (high risk of bias). All 13 evaluated studies reported selective outcomes describing the results and what had been identified (low risk of bias). These 13 studies were insufficient to assess other risks of bias (unclear risk of bias) (Figure 2).

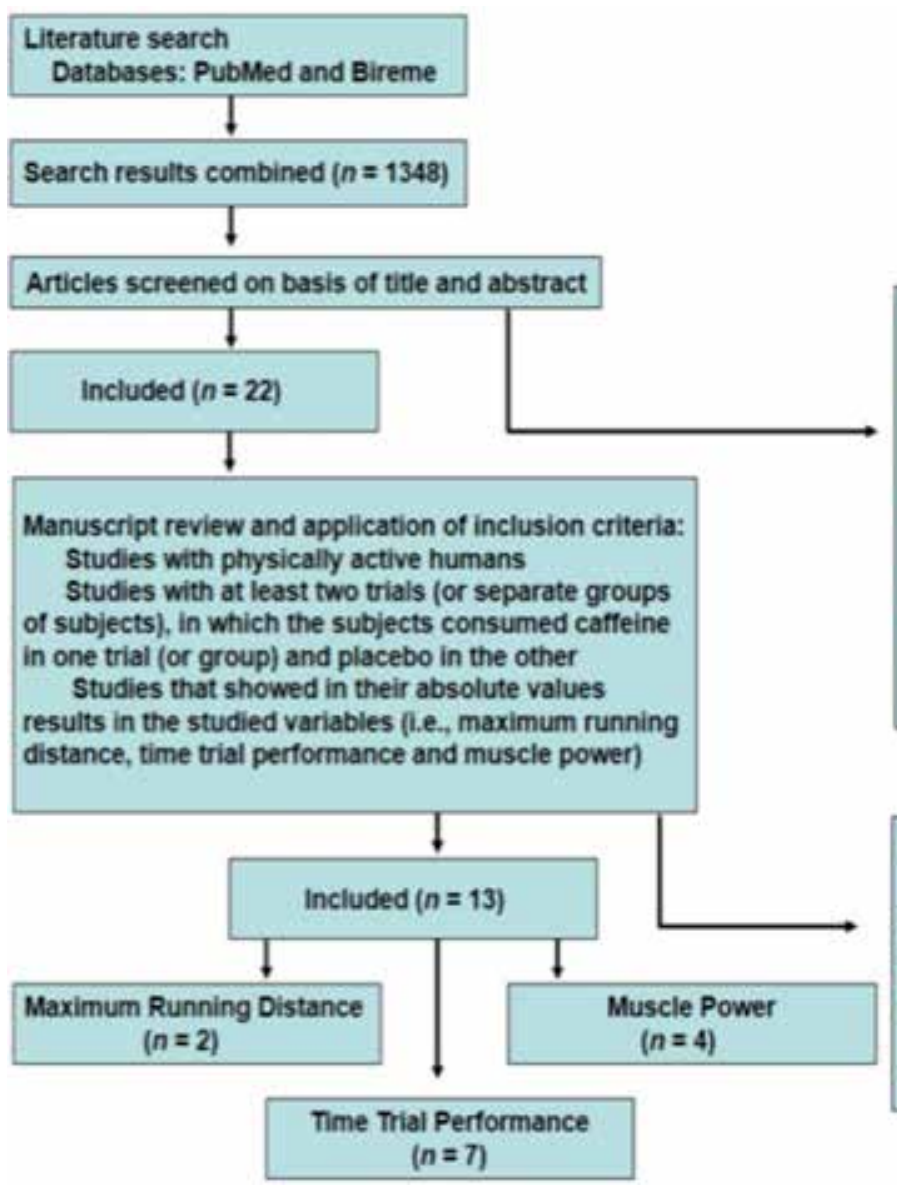

Figure 1. Flow chart of articles reviewed

Excluded ( $n=1326$ )
Use of co-ingested caffeine with
other known or potential ergogenic
compounds: 555
Trials that included women,
children, adolescents, and sedentary
men: 550
Studies that did not have full texts
(in such cases, an attempt was made
to retrieve the necessary data by e-
mailing the author: 213
Duplicity in the two search
criteria: 8

Excluded $(n=9)$

Studies that did not have full texts (in such cases, an attempt was made to retrieve the necessary data by $\mathrm{e}$ mailing the author: 8

Duplicity in the two search criteria: 1 
Table 1

General characteristic of the studies included in the systematic review and meta-analysis.

\begin{tabular}{|c|c|c|c|c|c|c|c|c|}
\hline Reference & $\begin{array}{c}\text { Form of } \\
\text { ingestion }\end{array}$ & Subjects info & $\begin{array}{l}\text { Caffeine } \\
\text { dosage }\end{array}$ & $\begin{array}{c}\text { Time of } \\
\text { consumption } \\
\text { pre-exercise (min) }\end{array}$ & $\begin{array}{c}\text { Measurement } \\
\text { Test }\end{array}$ & $\begin{array}{c}\text { Measurement } \\
\text { Unit }\end{array}$ & $\begin{array}{c}\text { Mean } \pm \text { SD } \\
\text { Caffeine }\end{array}$ & $\begin{array}{c}\text { Mean } \pm \text { SD } \\
\text { Placebo }\end{array}$ \\
\hline Acker-hewitt et al. (21) & Capsule & $\begin{array}{l}10 \text { male cyclists; } \\
28 \pm 9 \text { years; } \\
178 \pm 6 \mathrm{~cm} ; \\
73 \pm 6 \mathrm{~kg}\end{array}$ & $3(\mathrm{mg} / \mathrm{kg})$ & 60 & $\begin{array}{l}\text { Time Trial } \\
\text { Performance }\end{array}$ & Seconds & $2616 \pm 294$ & $2652 \pm 270$ \\
\hline Bortolotti et al. (5) & Capsule & $\begin{array}{c}13 \text { male cyclists; } \\
26 \pm 10 \text { years; } \\
176 \pm 6 \mathrm{~cm} ; \\
71 \pm 9 \mathrm{~kg}\end{array}$ & $6(\mathrm{mg} / \mathrm{kg})$ & 60 & $\begin{array}{c}\text { Time Trial } \\
\text { Performance }\end{array}$ & Seconds & $2181 \pm 194$ & $2191 \pm 158$ \\
\hline Glaister et al. (26) & Capsule & $\begin{array}{l}17 \text { well-trained } \\
\text { males; } \\
24 \pm 6 \text { years; } \\
182 \pm 0.06 \mathrm{~cm} \\
82.2 \pm 6.9 \mathrm{~kg}\end{array}$ & $\begin{array}{c}10 \\
(\mathrm{mg} / \mathrm{kg})\end{array}$ & 60 & $\begin{array}{l}\text { Muscle } \\
\text { Power }\end{array}$ & Watts & $1141 \pm 195$ & $1133 \pm 186$ \\
\hline Irwin et al. (4) & Capsule & $\begin{array}{c}12 \text { male cyclists; } \\
28.3 \pm 5.8 \text { years; } \\
183+0.04 \mathrm{~cm} ; \\
80.2 \pm 6.6 \mathrm{~kg}\end{array}$ & $3(\mathrm{mg} / \mathrm{kg})$ & 90 & $\begin{array}{c}\text { Time Trial } \\
\text { Performance }\end{array}$ & Seconds & $3443 \pm 272$ & $3572 \pm 272$ \\
\hline Marriott et al. (17) & Capsule & $\begin{array}{c}12 \text { male; } \\
20.8 \pm 1.4 \text { years; } \\
183 \pm 7 \mathrm{~cm} ; \\
78.9 \pm 5.4 \mathrm{~kg}\end{array}$ & $6(\mathrm{mg} / \mathrm{kg})$ & 70 & $\begin{array}{l}\text { Maximum } \\
\text { Running } \\
\text { Distance }\end{array}$ & Meters & $480 \pm 113$ & $413 \pm 121$ \\
\hline Skinner et al. (20) & Capsule & $\begin{array}{l}14 \text { male cyclists; } \\
31 \pm 5 \text { year; } \\
75.4 \pm 5.7 \mathrm{~kg}\end{array}$ & $6(\mathrm{mg} / \mathrm{kg})$ & 60 & $\begin{array}{l}\text { Time Trial } \\
\text { Performance }\end{array}$ & Seconds & $3476 \pm 97$ & $3546 \pm 123$ \\
\hline Souissi et al. (24) & Capsule & $\begin{array}{c}12 \text { male judoists; } \\
21.08 \pm 1.16 \text { years; } \\
1.76 \pm 6.57 \mathrm{~cm} ; \\
83.75 \pm 20.2 \mathrm{~kg}\end{array}$ & $5(\mathrm{mg} / \mathrm{kg})$ & 60 & $\begin{array}{l}\text { Muscle } \\
\text { Power }\end{array}$ & Watts & $935 \pm 209$ & $855 \pm 221$ \\
\hline Souissi et al. (25) & Capsule & $\begin{array}{c}13 \text { active males; } \\
21.1 \pm 1.1 \text { years; } \\
177 \pm 0.06 \mathrm{~cm} ; \\
77.1 \pm 7.2 \mathrm{~kg}\end{array}$ & $5(\mathrm{mg} / \mathrm{kg})$ & 60 & $\begin{array}{l}\text { Muscle } \\
\text { Power }\end{array}$ & Watts & $871 \pm 69$ & $863 \pm 77$ \\
\hline Spence et al. (22) & Capsule & $\begin{array}{c}10 \text { male cyclists; } \\
30 \pm 2 \text { years; } \\
79.10 \pm 1.65 \mathrm{~kg}\end{array}$ & $200(\mathrm{mg})$ & 60 & $\begin{array}{c}\text { Time Trial } \\
\text { Performance }\end{array}$ & Seconds & $4439 \pm 153$ & $4497 \pm 153$ \\
\hline Womack et al. (19) & Capsule & $\begin{array}{c}16 \text { male cyclists; } \\
25.0 \pm 7.3 \text { years; } \\
178.2 \pm 8.8 \mathrm{~cm} \\
74.3 \pm 8.8 \mathrm{~kg}\end{array}$ & $6(\mathrm{mg} / \mathrm{kg})$ & 60 & $\begin{array}{c}\text { Time Trial } \\
\text { Performance }\end{array}$ & Seconds & $4344 \pm 252$ & $4566 \pm 348$ \\
\hline
\end{tabular}




\begin{tabular}{|c|c|c|c|c|c|c|c|c|c|}
\hline \multicolumn{10}{|c|}{$\begin{array}{c}\text { Table } 2 \\
\text { Subgroup analysis for the effect of caffeine ingestion on maximum running distance, } \\
\text { time trial performance and muscle power using a random effect model. }\end{array}$} \\
\hline & \multicolumn{4}{|c|}{ Maximum Running Distance } & \multicolumn{2}{|c|}{$\begin{array}{c}\text { Time Trial } \\
\text { Performance }\end{array}$} & \multicolumn{2}{|r|}{ Muscle Power } & \multirow[b]{3}{*}{$\mathbf{p}$} \\
\hline & \multicolumn{4}{|c|}{ Effect size } & \multirow[b]{2}{*}{ Effect size $(95 \% \mathrm{CL})$} & \multirow[b]{2}{*}{$\mathbf{p}$} & \multicolumn{2}{|r|}{ Effect size } & \\
\hline & $\mathbf{n}$ & $(95 \% \mathrm{CL})$ & $\mathbf{p}$ & $\mathbf{n}$ & & & $\mathbf{n}$ & $(95 \% \mathrm{CL})$ & \\
\hline \multicolumn{10}{|l|}{ Dosage } \\
\hline $6 \mathrm{mg} / \mathrm{kg}$ & 1 & - & - & 4 & $-0.45(-0.81$ to -0.08$)$ & 0.01 & 1 & - & - \\
\hline$>6 \mathrm{mg} / \mathrm{kg}$ & - & - & - & - & - & - & 1 & - & - \\
\hline$<6 \mathrm{mg} / \mathrm{kg}$ & 1 & - & - & 3 & $-0.32(-0.80$ to 0.15$)$ & 0.18 & 2 & $0.26(-0.29$ to 0.81$)$ & 0.35 \\
\hline
\end{tabular}

Acker-Heiwitt et al. (21)

Bassini et al. (16)

Bortolotti et al. (5)

Desbrow et al. (18)

Glaister et al. (26)

Irwin et al. (4)

Marriott et al. (17)

Silva et al. (23)

Skinner et al. (20)

Souissi et al. (24)

Souissi et al. (25)

Spence et al. (22)

Womack et al. (19)

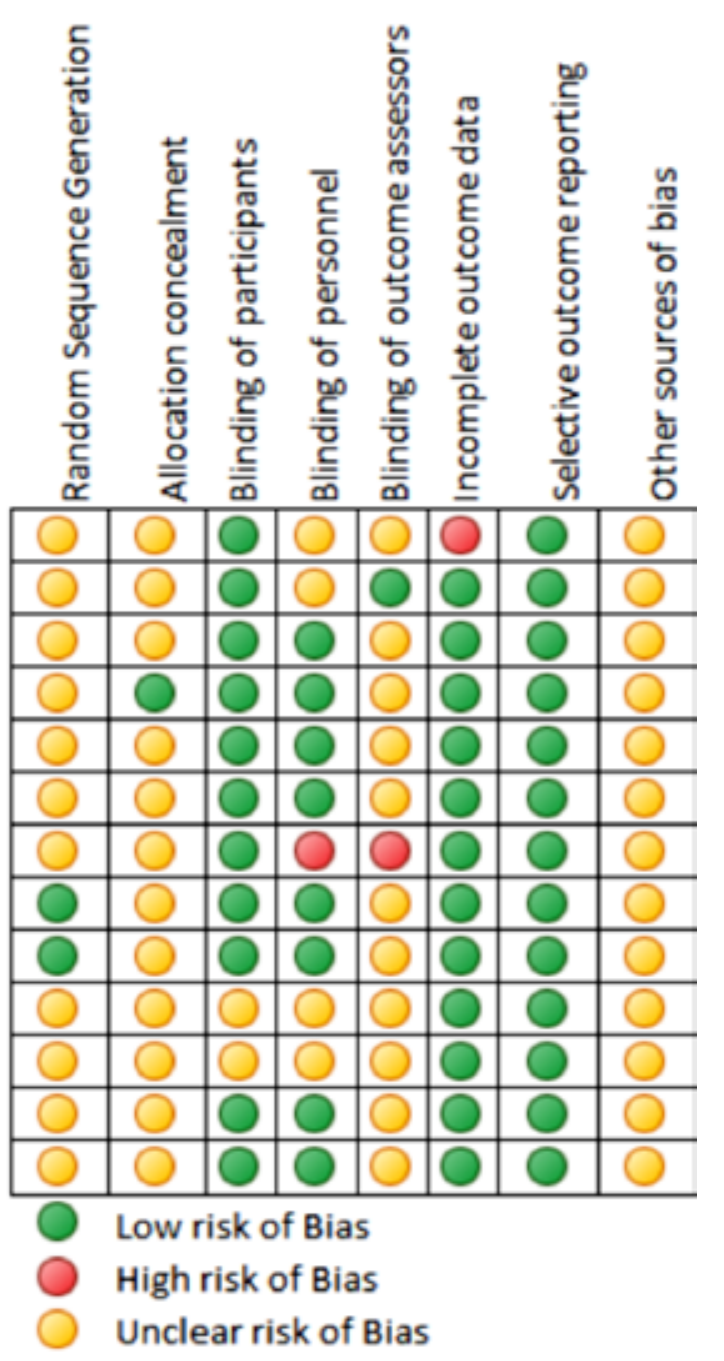

Figure 2. Summary of the quality of the 13 studies. 
Effect of caffeine intake on maximum running distance

Two of the studies applied the yo-yo test (i.e., field test designed to estimate the maximum oxygen uptake - $\mathrm{VO} 2 \mathrm{max}$ and the maximum running distance by athletes) to assess the maximum running distance of the subjects. The authors used caffeine dosage of $5 \mathrm{mg} / \mathrm{kg}$ of body weight ${ }^{16}$ and $6 \mathrm{mg} / \mathrm{kg}$ of body weight ${ }^{17}$ and found no improvement in the maximum running distance of the subjects (effect size $=0.37, p=0.14$, interpretation: small; Figure 3). The I2 statistic showed minimal heterogeneity between the studies $(I 2=0.00 ; p=0.55)$.

Effect of caffeine intake on time trial performance

Seven studies were included in the evaluation of time trial performance in cycling. Four of these studies used a caffeine dosage of $6 \mathrm{mg} / \mathrm{kg}$ of body weight ${ }^{5,18-20}$, two studies used a caffeine dosage of $3 \mathrm{mg} / \mathrm{kg}$ of body weight ${ }^{21,4}$ and one study used an intake fixed dose of $200 \mathrm{mg}$ of caffeine $(\sim 2.5 \mathrm{mg} / \mathrm{kg} \text { of body weight })^{22}$. Desbrow et al. ${ }^{18}$ and Irwin et al. ${ }^{4}$ evaluated the shortest time to reach a target amount of work among cyclists. Bortolotti et al. ${ }^{5}$ and Acker-Hewitt et al. ${ }^{21}$ applied a distance of $20 \mathrm{~km}$, whereas Spence et al. ${ }^{22}$, Skinner et al. ${ }^{20}$ and Womack et al. ${ }^{19}$ used a distance of $40 \mathrm{~km}$. The studies showed an improvement in time trial performance among the subjects who ingested caffeine (effect size $=-0.40, p<0.01$, interpretation: small; Figure 4). The I 2 statistic showed minimal heterogeneity between the studies $(12=0.00 ; p=0.87)$.

Effect of caffeine intake on muscle power

Four studies evaluated muscle power generated in cycling. Three of these studies ${ }^{23-25}$ used the Wingate test; the other study ${ }^{26}$ used seven sprints for a maximum of 10 seconds. The average dosage of caffeine was $6.5 \mathrm{mg} / \mathrm{kg}$ of body weight. The studies did not show an improvement in the muscle power generated by the subjects who ingested caffeine (effect size $=0.17, p=0.36$, interpretation: trivial; Figure 5). The 12 statistic showed minimal heterogeneity between the studies $(I 2=0.00 ; p=0.94)$.

\section{Maximum Running Distance}

\section{Study name}

Bassini et al. (16)

Marriott et al. (17)

\begin{tabular}{ccc} 
Std diff & \multicolumn{2}{c}{ Statistics for } \\
\cline { 2 - 3 } in means & $\begin{array}{c}\text { Lower } \\
\text { limit }\end{array}$ & $\begin{array}{c}\text { Upper } \\
\text { limit }\end{array}$ \\
0,256 & $-0,382$ & 0,895 \\
0,572 & $-0,244$ & 1,389 \\
0,376 & $-0,127$ & 0,879
\end{tabular}

Std diff in means and $95 \% \mathrm{CI}$

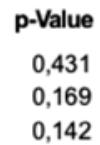

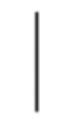

$-2,00$
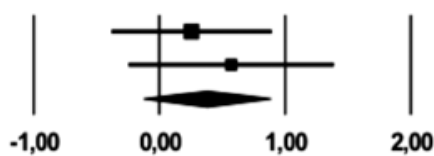

Placebo

Caffeine

Figure 3. Forest plot of the total effect size from the two studies that assessed the effect of caffeine intake on maximum running distance.

\section{Time Trial Performance}

\section{$\underline{\text { Study name }}$}

Acker-Hewitt et al. (21)
Bortolotti et al. (5)
Desbrow et al. (18)
Irmin et al. (4)
Spence et al. (22)
Skinner et al. (20)
Womack et al. (19)

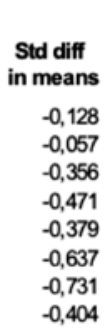

\begin{tabular}{cc}
\multicolumn{2}{c}{ Statistics for each study } \\
\hline $\begin{array}{c}\text { Lower } \\
\text { limit }\end{array}$ & $\begin{array}{c}\text { Upper } \\
\text { limit }\end{array}$ \\
$-0,929$ & 0,673 \\
$-0,825$ & 0,712 \\
$-1,054$ & 0,343 \\
$-1,283$ & 0,340 \\
$-1,263$ & 0,505 \\
$-1,396$ & 0,123 \\
$-1,446$ & $-0,015$ \\
$-0,695$ & $-0,112$
\end{tabular}

Std diff in means and $95 \%$ C

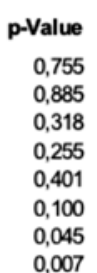

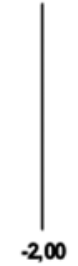

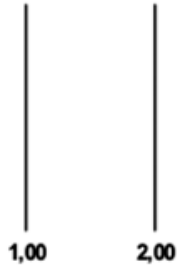

Placebo

Figure 4. Forest plot of the total effect size from the seven studies that assessed the effect of caffeine intake on time trial performance. 
Muscle Power

\begin{tabular}{|c|c|c|c|c|}
\hline \multirow[t]{2}{*}{$\underline{\text { Study name }}$} & \multicolumn{4}{|c|}{ Statistics for each study } \\
\hline & $\begin{array}{l}\text { Std diff } \\
\text { in means }\end{array}$ & $\begin{array}{l}\text { Lower } \\
\text { limit }\end{array}$ & $\begin{array}{c}\text { Upper } \\
\text { limit }\end{array}$ & p-Value \\
\hline Glaister et al. (26) & 0,042 & $-0,630$ & 0,714 & 0,903 \\
\hline Silva et al. (23) & 0,203 & $-0,675$ & 1,082 & 0,650 \\
\hline Souissi et al. (24) & 0,375 & $-0,432$ & 1,182 & 0,363 \\
\hline Souissi et al. (25) & 0,157 & $-0,613$ & 0,927 & 0,690 \\
\hline & 0.178 & $-0,208$ & 0,563 & 0,366 \\
\hline
\end{tabular}

Std diff in means and $95 \% \mathrm{Cl}$

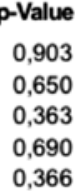

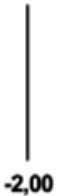

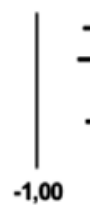

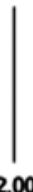

Placebo

Caffeine

\section{DISCUSSION}

The aims of this systematic review and meta-analysis were to evaluate the effects of caffeine supplementation on athletic performance. The main finding of this study was that caffeine improves performance on the time trials performance, but not on maximum running distance and muscle power test. In addition, subgroup analysis revealed that the effect of caffeine in the time trials performance test may be related to $6 \mathrm{mg} / \mathrm{kg}$ of body weight dosage.

The exact mechanisms by which caffeine exerts ergogenic effects are still under debate, with suggested mechanisms including fatty acid mobilization and oxidation and endogenous glycogen content sparing, attenuating fatigue ${ }^{27}$. The studies included in the evaluation of the maximum running distance did not improved performance with the use of caffeine $(\mathrm{p}=$ 0.14). In the individual analysis of the studies there was no response of caffeine. According to the hypothesis of Bassini et al. ${ }^{16}$, the hyperammonic state changes the function of the blood-brain barrier and is postulated to cause central fatigue during exercise. However, we observed that the maximum running distance was small to induce hyperammonemia in athletes and consequently it was also small to test the positive ergogenic effect of caffeine. Marriot et al. ${ }^{17}$ reported high variation in maximum running distance between assessed subjects, which they attributed to the existence of "high" and "low" responders to caffeine.

Subgroup analyses revealed that the improvement in time trial results may be related to the dose. According to Desbrow et al. ${ }^{18}$, the use of high caffeine dosage could increase blood concentration of epinephrine and improve performance during the time trials performance test. Skinner et al. ${ }^{20}$ explained that independent of dosage, for the ergogenic benefit of the peripheral action of caffeine to occur, greater availability of muscle is required (i.e., increased concentrations of caffeine at the site of action). Additionally, Irwin et al. ${ }^{4}$ showed that acute caffeine supplementation positively affected exercise performance. The positive ergogenic effect of caffeine was found to be related to alteration in the rating of perceived exertion. Desbrow et al. ${ }^{18}$ suggested that this mechanism (i.e., the central effects mediated by adenosine receptor antagonism) might explain the ergogenic effect of caffeine on exercise performance by using the time trials performance.

The null findings obtained in the studies of Acker-Hewitt et al. ${ }^{21}$ and Bortolotti et al. ${ }^{5}$ may relate to the nature of the performance protocol. Bortolotti et al. ${ }^{5}$ used closed-loop protocol time trials. This allowed for the development of strategies during the test to finish in the shortest possible time, preventing the athlete from reaching exhaustion. On the other hand, although different doses of caffeine were used, there were similarities in the methodologies applied by Bortolotti et al. ${ }^{5}$, Acker-Hewitt et al. ${ }^{21}$, and Spence et al. ${ }^{22}$. In these three studies, participants ingested caffeine 60 minutes before the test and were instructed not to ingest any food or drink that might contain caffeine 48 hours before testing.

Regular consumption of caffeine has been associated with an upregulation of the number of adenosine receptors in the vascular and neural tissues of the brain ${ }^{28,29}$. Based on these observations, it could be speculated that habitual and non-habitual caffeine consumers would respond differently to caffeine supplementation during exercise. The minimum period of caffeine fasting in diet that is needed to obtain greater sensitivity to its action is not well established in the literature. Tavares and Sakata ${ }^{30}$ indicated that the time required for the beginning of abstinence varies between 12 and 24 hours after cessation of consumption but could range between 48 and 216 hours. In the articles evaluated in the current study, it is possible that the subjects had low sensitivity to caffeine, which would require a longer period of abstinence and/or an increase in the dosage used. In particular, in Spence et al. ${ }^{22}$, subjects were consumers of caffeine; thus, the dosage of $2.5 \mathrm{mg} / \mathrm{kg}$ of body weight used may be considered low. In fact, Warren et al..$^{31}$ indicated in their meta-analysis that the commonly used caffeine dosage was $4-6 \mathrm{mg} / \mathrm{kg}$ of body weight.

These results reinforce the notion that responses to caffeine may be triggered by other factors, such as genetics, 
rather than habitual caffeine intake per se. According to Womack et al. ${ }^{19}$, genetic polymorphisms in genes related to caffeine metabolism (aryl-hydrocarbon receptor [AHR], cytochrome P450 1A1 and 1A2 (CYP1A1-CYP1A2, Prenyl (Decaprenyl)) are a potential explanation for the variability in the ergogenic response to caffeine supplementation in trained cyclists. These authors reported a significant main effect of supplementation with $6 \mathrm{mg} / \mathrm{kg}$ of body weight of anhydrous caffeine on the performance of cyclists. Given these prior findings, it could be hypothesized that a slower metabolism would be advantageous for maximizing the ergogenic benefit of caffeine. However, the major finding of their study was that caffeine affected the $40-\mathrm{km}$ TT performance of cyclists homozygous for the AA (i.e., caffeine is metabolized at a higher rate) variant to a greater degree compared with cyclists with the $\mathrm{C}$ (i.e., caffeine is metabolized at a lower rate) variant. Specifically, caffeine decreased the $40-\mathrm{km}$ TT time by an average of 3.8 minutes in the AA homozygotes compared with 1.3 minutes in the C-allele carriers. The authors speculate that the rapid accumulation of caffeine metabolites may have been responsible for the positive ergogenic effect in AA homozygotes. Paraxanthin and theophylline (metabolites downstream of caffeine metabolism) have higher binding affinities with adenosine receptors than caffeine ${ }^{32}$. Thus, it is possible that a faster caffeine metabolism in AA homozygotes created a faster production of paraxanthine and/or theophylline and thus increases the ergogenic effect.

It has been suggested that caffeine increases strength and muscle power performance through greater motor unit firing rates, increased calcium release from the sarcoplasmic reticulum, and surges in nitric oxide concentrations, working collectively to produce stronger muscle contractions $s^{33}$. However, it is possible that slow-twitch fibers are more sensitive to such action than fast-twitch fibers ${ }^{34,35}$, which could help to explain the limited ergogenic effect upon maximal strength and muscle power. In their evaluation of the contractile properties of skeletal muscle, Souissi et al. ${ }^{24}$, Souissi et al. ${ }^{25}$, Silva et al. ${ }^{23}$ and Glaister et al. ${ }^{26}$ suggest that the positive benefit of caffeine use in cyclists may be more effective in longer time evaluations of muscle power compared to shorter tests. Thus further research is needed to elucidate the ergogenic effects of caffeine during muscle strength exercises.

\section{CONCLUSION}

In conclusion, this meta-analysis showed that caffeine intake does not improve performance in maximum running distance and muscle power, but seems to improve time trial performance. The potential effect of caffeine on time trial performance related to caffeine dose. The results of the present study contribute to the knowledge of the ergogenic effects of caffeine in several tests that evaluate athletic performance.

Financial Support This work was supported by Research Support Foundation of Rio de Janeiro FAPERJ - Brazil. Edict
Innovations in Sports E-26/190.298. FAPERJ had no role in the design, analysis or writing of this article.

Conflicts of Interest The authors declare that there are no conflicts of interest in the present study.

The authors' contributions are as follows:

B.G.R and A.A.M (Nutritionist) designed the database, carried out the majority of the meta-analysis and contributed to the writing and the critical review of the manuscript;

F.S.J (Physiotherapist) helped to design the literature search and database storage and helped to design and provided guidance for the meta-analyses used;

F.T (Physical Education Teacher?) carried out a major part of the literature search, and extraction and contributed to the writing of the manuscript;

A.P.M (Physical Education Teacher?) contributed to the literature review and the discussion of manuscript;

T.C.L (Nutritionist) helped with the literature review and provided a critical revision of the manuscript, especially the discussion of results.

\section{RESUMEN}

Objetivo: Realizar una revisión sistemática y meta-análisis de la literatura de investigación que evalúa el efecto de la cafeína en el rendimiento atlético. Método: Un total de 13 estudios publicados entre 2010 y 2015 fueron incluidos en el meta-análisis de los efectos de la cafeína sobre la distancia máxima de carrera (2 estudios), el tiempo de prueba ( 7 estudios) y la potencia muscular (4 estudios). Los tamaños del efecto se calcularon como diferencias estandarizadas en las medias (std en los medias), y el meta-análisis se completó utilizando un modelo de efectos aleatorios. Resultados: La suplementación con cafeína no aumentó la distancia máxima de funcionamiento (tamaño del efecto= $0.37, p=0.14$ ) ni la potencia muscular (tamaño del efecto= $0.17, p=0.36$ ). Sin embargo, se observaron mejoras en el rendimiento del ensayo con tiempo (tamaño del efecto= $-0.40, p<0,01)$. Los análisis de subgrupos revelaron que la mejora en los resultados de los ensayos a tiempo podía estar relacionada con el uso de la dosis de $6 \mathrm{mg} / \mathrm{kg}$ de peso corporal de cafeína (tamaño del efecto $=-0.45, \mathrm{p}=0.01$ ). Conclusiones: El meta-análisis demostró que la ingesta de cafeína no mejora el rendimiento en la distancia máxima de carrera ni la potencia muscular, pero parece mejorar el rendimiento de la prueba de tiempo. Este efecto potencial de la cafeína en el rendimiento de la prueba de tiempo estuvo relacionado con la dosis.

Palabras clave: cafeína, funcionamiento, prueba de ejercicio, ciclo, energía del músculo.

\section{REFERENCES}

1. Del Coso J. Muñoz G. Muñoz-Guerra J. Prevalence of caffeine use in elite athletes following its removal from the World Anti-Doping Agency list of banned substances, Appl Physiol Nutr Metab 2011; 36: 555-561.

2. Desbrow B. Leveritt M. Awareness and use of caffeine by 
athletes competing at the 2005 Ironman Triathlon World Championships, Int I Sport Nutr Exerc Metab 2006; 16: 545-558.

3. Desbrow B. Leveritt M. Well-trained endurance athletes' knowledge, insight, and experience of caffeine use, Int J Sports Nutr Exerc Metab 2007; 17: 328-339.

4. Irwin C. Desbrow B. Ellis A. Rant BO. Leveritt M. Caffeine withdrawal and high-intensity endurance cycling performance, J Sports Sci 2011; 29: 509-515.

5. Bortolotti H. Altimari LR. Vitor-Costa M. Cyrino ES. Performance during a 20-km cycling time-trial after caffeine ingestion, J Int Soc Sports Nutr 2014; 11: 1-7.

6. Clausen T. Na+-K+ pump regulation and skeletal muscle contractility, Physiol Rev 2003; 83: 1269-1324.

7. Doherty M. Smith P. Hughes M. Davison R. Caffeine lowers perceptual response and increases power output during high intensity cycling. I Sports Sci 2004; 22: 637-643.

8. Roy BD. Bosman MJ. Tarnopolsky MA. An acute oral dose of caffeine does not alter glucose kinetics during prolonged dynamic exercise in trained endurance athletes, Eur J Appl Physiol 2001; 85: 280- 286.

9. Van Soeren MH. Sathasivam P. Spriet LL. Graham TE. Caffeine metabolism and epinephrine responses during exercise in users and nonusers, J Appl Physiol 1993; 75: 805-812.

10. Davis JM. Zhao Z. Stock HS. Mehl KA. Buggy J. Hand GA. Central nervous system effects of caffeine and adenosine on fatigue, Am J Physiol Regul Integr Comp Physiol 2003; 284 : 399-404.

11. An SM. ParkJS. Kim SH. Effect of energy drink dose on exercise capacity, heart rate recovery and heart rate variability after high-intensity exercise, J Exerc Nutrition Biochem 2014; 18 : 31-39.

12. Goldstein E. Jacobs PL. Whitehurst M. Penhollow T. Antonio J. Caffeine enhances upper body strength in resistance-trained women, J Int Soc Sports Nutr 2010; 14: 7-18.

13. Jacobs I. Pasternak H. Bell DG. Effects of ephedrine, caffeine, and their combination on muscular endurance, Med Sci Sports Exerc 2003; 35: 987-994.

14. Williams AD. Cribb PJ. Cooke MB. Hayes A. The effect of ephedra and caffeine on maximal strength and power in resistance trained athletes, I Strength Cond Res 2008; 22: 464-470.

15. Higgins JP. Altman DG. Gøtzsche PC. Jüni P. Moher D. Oxman AD. Savovic J. Schulz KF. Weeks L. Sterne JA. Cochrane Bias Methods Group. Cochrane Statistical Methods Group. The Cochrane Collaboration's tool for assessing risk of bias in randomised trials, BMJ 2011; 343: d5928.

16. Bassini A. Magalhães-neto AM. Sweet E. Bottino A. Veiga C. Marta B. Tozzi MB. Pickard MB. Cameron L. Caffeine decreases systemic urea in elite soccer players during intermittent exercise, Med Sci Sports Exerc 2013; 45: 683-690.

17. Marriott M. Krustrup P. Mohr M. Ergogenic effects of caffeine and sodium bicarbonate supplementation on intermittent exercise performance preceded by intense arm cranking exercise, I Int Soc Sports Nutr 2015; 12: 1-8.

18. Desbrow B. Biddulph C. Devlin B. Grant GD. AnoopkumarDukie S. Leveritt MD. The effects of different doses of caffeine on endurance cycling time trial Performance, J Sports Sci 2011; 30: 115-120.
19. Womack CJ. Saunders MJ. Bechtel MK. Bolton DJ. Martin M. Luden ND. Dunham W. Hancock M. The influence of a CYP1A2 polymorphism on the ergogenic effects of caffeine, J Int Soc Sports Nutr 2012; 9: 1-7.

20. Skinner TL. Jenkins DG. Taaffe DR. Leveritt MD. Coombesa JS. Coinciding exercise with peak serum caffeine does not improve cycling performance, J Sci Med Sport 2013; 16: 54-59.

21. Acker-Hewitt TL. Shafer BM. Saunders MJ. Goh Q. Luden $N D$. Independent and combined effects of carbohydrate and caffeine ingestion on aerobic cycling performance in the fed state, Appl Physiol Nutr Metab 2012; 37: 276-283.

22. Spence AL. Sim M. Landers G. Peeling P. A comparison of caffeine versus pseudoephedrine on cycling Time-Trial performance, Int I Sports Nutr Exerc Metab 2013; 23: 507512.

23. Silva CG. Cavazzotto TG. Queiroga MR. Supplementation of caffeine and anaerobic power indicators, Rev Educ Fís 2014; 25: 109-116.

24. Souissi M. Abedelmalek S. Chtourou H. Atheymen R. Hakim A. Sahnoun Z. Effects of morning caffeine ingestion on mood states, simple reaction time, and short-term maximal performance on elite judoists, Asian J Sports Med 2012; 3: 161-168.

25. Souissi M. Chtourou H. Abedelmalek S. Ghozlane IB. Sahnoun $Z$. The effects of caffeine ingestion on the reaction time and short-term maximal performance after $36 \mathrm{~h}$ of sleep deprivation, Physiol Behav 2014; 131: 1-6.

26. Glaister M. Patterson SD. Foley P. Pedlar CR. Pattison JR. Mclnnes G. Caffeine and sprinting performance: dose responses and efficacy, / Strength Cond Res 2012; 26: 1001-1005.

27. Magkos F. Kavouras SA. Caffeine use in sports, pharmacokinetics in man, and cellular mechanisms of action, Crit Rev Food Sci Nutr 2005; 45: 535-562.

28. Fredholm BB. Adenosine actions and adenosine receptors after 1 week treatment with caffeine, Acta Physiol Scand 1982; 115: 283-286.

29. Fredholm BB. Battig K. Holmen J. Nehlig A. Zvartau EE. Actions of caffeine in the brain with special reference to factors that contribute to its widespread use, Pharmacological reviews 1999; 51: 83-133.

30. Tavares C. Sakata RK. Caffeine in the treatment of pain, Rev Bras Anestesiol 2012; 62: 387-401.

31. Warren GL. Park ND. Maresca RD. McKibans KI. MillardStafford ML. Effect of caffeine ingestion on muscular strength and endurance: a meta-analysis, Med Sci Sports Exerc 2010; 42: 1375-1387.

32. Daly JW. Butts-Lamb P. Padgett W. Subclasses of adenosine receptors in the central nervous system: interaction with caffeine and related methylxanthines, Cell Mol Neurobiol 1983; 3: 69-80.

33. Kalmar JM. The influence of caffeine on voluntary muscle activation, Med Sci Sports Exerc 2005; 37: 2113-2119.

34. Mitsumoto H. DeBoer GE. Bunge G. Andrish JT. Tetzlaff JE. Cruse RP. Fiber-type specific caffeine sensitivities in normal human skinned muscle fibers, Anesthesiol 1990; 72: 50-54.

35. Pagala MK. Taylor SR. Imaging caffeine-induced Ca2+transients in individual fast-twitch and slow-twitch rat skeletal muscle fibers, Am J Physiol 1998; 274: C623-632. 